\title{
OBITUARIES/HULDEBLYKE
}

\section{Edward Joseph (Joe) Stewart}

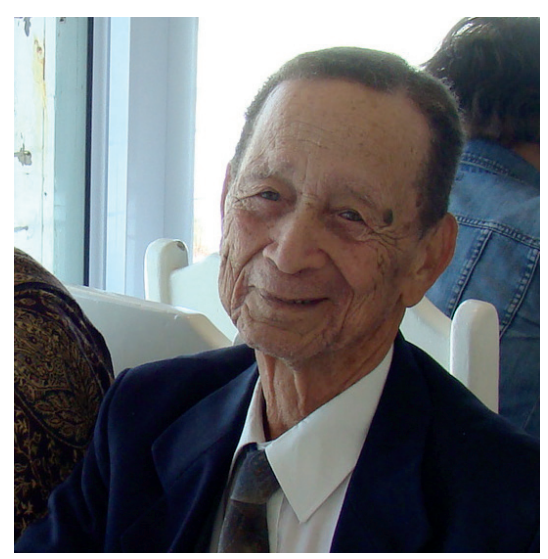

Edward Joseph Stewart (1926 - 2013) was born in 1926 in Swaziland. He travelled to Cape Town for further education, first at Zonnebloem College, then Trafalgar High School. He graduated MB ChB at UCT in 1951, the first Swaziland-born medical graduate. After considering community practice in Kenya, he met his wife, Dulcima Maurice, and they settled in Cape Town. He established a private general practice, first in Vasco and then in Elsies River - his home for almost fifty years. Joe epitomised integrity and honesty. His dedication to the interests of his patients above all else made him the quintessential family practitioner, caring for families of patients spanning generations. He never hesitated to make house-calls in the middle of the night, or to open the surgery during Sunday lunch, often to the chagrin of his family.

Joe worked in an underprivileged community, and always put patient care above monetary gain. He was panel doctor for a number of sick funds, such as the Furniture Workers' Sick Fund, and did pro bono work for the local convent. He frequently went beyond the call of duty. I recall a time when he was managing a longstanding elderly patient at home with IV antibiotics. He visited her three times a day to change the drip and administer the antibiotics. He often assisted with his patients' operations, once taking a patient off the theatre table when he believed a procedure to be incorrect. Even in his 80 s, many patients insisted on his continuing to treat them.

Joe's interests included medical ethics, and he completed a two-year ethics course for general practitioners. A friend, mentor and confidant to many of his patients, Joe spent many hours discussing their problems, gaining close insights into people's complicated lives and receiving their gratitude and respect in return. He was an institution in Elsies River. A man passing his gate asked: 'Is u Dr Stewart? Ek dog Doc is lank dood. Hoe oud is Doc nou?' Joe replied: 'So om en by honderd.' The man nodded solemnly: 'Mens kan mos sien.'

Joe was active in local politics and a founder member of the Dispensing Family Practitioners' Association (DFPA), formed in 1984 in response to legislation precluding doctors from dispensing. SAMA was later formed by merging the Medical Association of South Africa (MASA) and several other organisations including the DFPA. Joe remained modest and humble, refusing acknowledgement for his contributions.

A keen photographer and an avid gardener, he cultivated roses and orchids. He was unstintingly loving and loyal to his wife and daughter and maintained close ties with his wider family. Latterly he began compiling anecdotes from his practice. A fervent reader of medical journals, he maintained his CPD activities - his last CPD certificate arrived two weeks after his death. In hospital, his doctors were amazed to see his bedside reading material, Scientific American.

Joe bore his illnesses with dignity, fortitude and immeasurable fighting spirit. Determined to maintain his strength and independence, working with his physio to this end became his daily goal. Despite the challenges he endured, his most inspiring quality towards the end was his acceptance of change, his ability to make the best of his situation and his ongoing engagement with the patients who visited, reminisced with and supported him.

I am honoured to have known him both as colleague and as father, and to have experienced his mentorship and encouragement, and the high standards of medical and ethical care he set himself.

\section{Chantal Stewart}

Groote Schuur Hospital and UCT

cstewart@global.co.za 